\title{
Whigs and professionals
}

\author{
In recent years study of the history of science has been transformed. \\ Colin Russell discusses the change in attitudes.
}

FOR most working scientists, excursions into the history of science are rather like eating Easter eggs: a harmless amusement, enjoyed by the very young and the very old, but strictly for holidays. Heroic tales from the past glories of science have long been deemed appropriate for youthful readers, and much history of science has been written by elderly, if not retired, scientists with half an eye on their own niche in the hall of fame. In fact both these characterizations of history of science - juvenile improvement or geriatric propaganda - are really caricatures. But if once they were partly true they are mercifully so no longer.

In the past 25 years or so, study of the history of science has changed out of all recognition. In a word it has been "professionalized". It is taught in several hundred universities in the Western world. A new breed of professionals, equally hungry for knowledge and anxious to display their skills, sustain a whole range of specialist journals and societies. Whatever be the causes (and they are complex), the professionalization of history of science and history of technology has not only given the subject its most substantial boost so far but has also posed new problems.

The raising of professional standards of scholarship really does mean that the "old" history of science is no longer adequate. It simply will not do, for instance, for books to be produced without references, adequate documentation or an index. Popular works that ignore such aids to the reader will have only the most limited value nowadays. Archimedes's bath, Newton's apple and Wohler's destruction of vitalism are myths (and clichés) best forgotten in the light of modern scholarship. But these are relatively trivial matters. One of the rudest words which the new professionals love to apply to what they see as outmoded history of science is "Whiggish". To indicate the depth of opprobrium associated with this apparently mild epithet, let me give an example.

In 1899 one H.W. Picton published The Story of Chemistry, complete with a commendatory preface from Sir Henry Roscoe. Chemical history was divided into nine periods, the first four taking us up to the middle of the eighteenth century. The next three were: "The Childhood of Truth", "The Conflict with Error" and
"The Triumph of Truth". Picton saw chemical history as the inexorable, if gradual, conquest of error (which he called "'mysticism") by truth. Those, like the phlogistonists, who opposed and retarded the emergence of the true oxygen theory of combustion, were given short shrift. The establishment and triumph of the British Empire.

Picton was quite typical of his time, and history of science still has its own brand of Whigs. These continue to present science in triumphalist terms, very flattering to the scientific community but curiously devoid of any inkling that science might - just might - be unable to control its own destiny and that of the human race. Was not a most successful television series entitled The Ascent of Man? Yet this was, as Professor S.L. Jaki has reminded us in Angels, Apes and Men (Sherwood Sugden, 1983), "an old shoe stitched together with Darwinian inconsistencies"' (p.61). Claiming to derive values from facts, it seemed blissfully unaware of the culturally generated assumptions in the mind of Darwin and his followers.

The difficulty, of course, is that in some respects the Whigs are perfectly right. The scientific method does, if properly applied, expose errors and lead to an ever greater apprehension of truth about nature. It is a very perverse historiography that ignores that fact. But it is equally perverse to imagine that the practitioners of science operate in a cultural vacuum. They, and we, are affected by the prevailing climate of opinion and this will have a profound effect on how science is perceived. Isaac Newton had only one head. The same brain which processed the theory of universal gravitation also preoccupied itself with matters of state, with personal problems in his family, with speculations about alchemy and with great issues of Biblical study and theology. It is foolish to imagine that Newton or anyone else could compartmentalize his intellectual life to such an extent that his science was completely autonomous. If we really want to understand how science developed we shall ignore its wider context at our peril. This is one pitfall mercilessly exposed by contemporary work in history of science.

In stepping gingerly round this one, however, we are in imminent danger of falling into another. Given that the history of science can only be understood in a mature way by taking into account all kinds of other influences, the subject becomes fair game for those who have an ideological axe to grind, consciously or not. Thus some Victorian writers, intoxicated with the idea of progress and unimpressed by the filibustering of the established church in the wake of Darwinism, rewrote the history of science in terms of a conflict between science and religion, whose outcome was as inevitable as any good Whig could expect. One particularly notorious work of 1875 , History of the Conflict Between Religion and Science by the American pioneer in photochemistry J.W. Draper, was still in print a year or two ago, as was its less vitri- 
olic successor of $1895, A$ History of the Warfare of Science with Theology by A.D. White of Cornell. These books represent the fag-end of a tradition which, if no longer alive and kicking, is still able to display some vestigial traces of animation. Today historical justification for that position is amazingly hard to justify. It is widely accepted on all sides that, far from undermining it, science is deeply indebted to Christianity and has been so from at least the Scientific Revolution. Recent historical research has uncovered many unsuspected links between scientific enterprise and Biblical theology. The "conflict" model is not just a harmless anachronism. It is truth standing on its head.

Or again, an early Marxist view of Newton purported to explain his Principia largely in terms of social and economic forces. Since then various attempts have been made to reduce science to a social epiphenomenon and nothing more. Probably on account of their huge if unspoken assumptions, historical essays of this kind have not been conspicuously successful. Such crudities carry little weight today, yet they can remind us of more subtle ways in which our own presuppositions can nurture a distorted view of the history of science. In a recent lecture published in the Times Higher Education Supplement (2 March 1984), the Oxford historian of science, A.C. Crombie, has warned us against "politicized historiography" as fiction disguised as truth. Its ultimate condemnation is that it aims "to promote a party line . . . by exploiting the trust upon which a true republic of letters must rest". Whether this exploitation is from the political right or left it is also the republic of science which is in danger, and the threat must be taken seriously. Whether perfect objectivity can ever be obtained in science or history is another matter. But it's not a bad thing to aim for.

If modern history of science has exposed some of the old pitfalls in a new light it has also invented some of its own. Perhaps the most obvious transformation in recent years is that, in some areas, history of science is no longer fun. The feeling seems to be abroad that the hallmarks of scholarship must be an over-serious, if not pontifical, exposition. If the reader is bored out of his mind, that is his fault, not the author's. This is a great pity because many of the insights so painfully won and meticulously documented are of real importance for those who practise, teach or administer the sciences. Fortunately there are still many distinguished scholars whose lucid writings confound these criticisms and make excellent reading. But there are some who don't, and that is a pity.

Perhaps the biggest danger of professionalization lies in its exclusiveness. There is a tendency in some quarters to cultivate a language and style that is all very well in internal communications but not at all helpful if a wider audience is addressed. Articles replete with personalized opinions, with footnotes longer than the text, with arcane references to "paradigms", "hegemony", "cultural legitimation" and so on cut little ice with those outside the favoured circle. Sadly, I can of fer little encouragement to writers of such material that their work commands attention from the many active scientists who, nevertheless, may be quite interested in the origins of their subjects.

At a conference some years ago to celebrate the bicentenary of an important British scientist, papers were planned about his literary work, his reforming ideals, his public lectures, his institutional affiliations - even his sporting life! Only as an afterthought was anything proposed concerning his science, though that was the single reason for his importance. Instances like this can be multiplied. They arise when a rightful concern with the context of science has been extended to an almost monomaniac obsession, to the virtual exclusion of its content. The effect is simply to alienate large numbers of potential readers whose interest is primarily in the science itself. But does it matter?

Certainly it does. Science without its history is like a man without a memory. The results of such collective amnesia are dire. In chemistry, for instance, most of the great histories over the past 200 years were not written, as is often alleged, by chemists in their dotage, but rather in their prime of life. At least they thought historical studies conveyed some of that most desirable commodity "relevance". And so they do. They help us to understand something of the forces, internal and external, which fashion the shape of science, whether in the structure of scientific theories, the nature of experiments, the influence of religion or politics, the role of education and so on. They can save us from the bankruptcy of Whiggish triumphalism. They can add to our teaching a human dimension that can demonstrably reduce the alienation from science displayed by many young people in recent years. And, in rare cases, they can even assist us at the laboratory bench. Remember Lord Rayleigh and the inert gases?

The history of science was once conceived as part of science. Quite rightly, recent historians have come to see that it is also an important part of history. I believe that it is part of both. It has recently been argued that German history of science has failed to progress beyond narrow scientific confines, and to address itself to a wider audience of historians, sociologists and others. In the English-speaking world, however, we appear to suffer from the opposite malaise. So far has our pendulum swung towards history that we often fail to communicate with the world from which our subject sprang: the world of science itself. For historians to suppose that this does not matter would seem to imply a most curious evaluation of their own work. It almost suggests that modern science does not need to take into account its origins and that it would have happened anyway. That is the most Whiggish philosophy of all! However, there are signs that a new synthesis is emerging and the reluctance to

"Newton with his prism and silent face", the personification of scientific abstraction. The first seven words are those of William Wordsworth, describing the Roubilliac bust in Trinity College Cambridge.

consider issues internal to science itself is diminishing. In so far as this engages the interest of a new generation of potential scientists it is surely to be welcomed.

One of the most encouraging signs of renewed interest amongst scientists is the emergence of historical groups within the larger scientific societies. For some years such groups have existed for chemistry, astronomy and one or two other sciences. Now they are enjoying a new prosperity, and they are being joined by analogues in the life sciences, geology and other subjects. In my experience some of the most stimulating, enthusiastic and perceptive discussions in the history of science have taken place in such settings, both in Britain and elsewhere.

A recent celebration of the 250th anniversary of the birth of Joseph Priestley drew capacity audiences. They listened to historical papers ranging from Priestley as a victim of political caricature, through the relations between his theology and his chemistry, to the growth of pneumatic chemistry and the techniques available for gas analysis. This was in the middle of a highly technical, scientific conference. It is not in the least unique and is simply one illustration of two most desirable trends now discernible in the history of science: that it must be fully alive to the cultural context out of which science developed, and that it must also be earthed in the practice and theory of the science whose development it seeks to describe.

Colin Russell is Professor of History of Science and Technology at the Open University. His most recent book is Science and Social Change 1700-1900 (Macmillan/St Martin's Press, 1983). 